\title{
Effectiveness of various elements of grain cultivation technology
}

\author{
Fedor A. Popov, Evgeniya N. Noskova*, and Lyudmila M. Kozlova
}

Federal Agricultural Research Center of the North-East named N.V. Rudnitsky, 610007 Kirov, Russian Federation

\begin{abstract}
The article presents the results of a long-term stationary threefactor experiment on sod-podzolic loamy soil to identify the effectiveness of various methods of basic and pre-sowing treatment of soil, the use of biological preparations in the technology of cultivating grain crops in sixfield crop rotation. It was established that the most profitable elements of the technology in energy and economic terms will be: surface-cut treatment with KPS-4 cultivator and introduction of Azotovit and Phosphatovit biologics into the tillering stage of oat in a vetch-oat mixture for green feed; surface-cut treatment with KBM-4,2 cultivator or with pre-sowing treatment with a APPN-2,1 combined aggregate and introduction of Azotovite and Phosphatovite biological preparations into the soil before sowing winter rye for grain; ploughing with pre-sowing treatment with APPN-2,1 combined aggregate for spring wheat; surface-cut treatment with pre-sowing treatment with APPN-2,1 combined aggregate and introduction of biologic preparation based on strain Streptomyces hygroscopicus A4 at tillering stage of oat in pea-oat mixture for grain-hay; ploughing with KPS-4 cultivator and introduction of Pseudobacterin-2 biopreparation at barley tillering stage; ploughing with pre-sowing treatment with APPN-2,1 combined aggregate and introduction of biologic preparation based on strain Streptomyces hygroscopicus A4 at oat tillering stage.
\end{abstract}

\section{Introduction}

An urgent problem of agricultural production is the provision of food to the population. This problem needs to be solved comprehensively, taking into account many factors. One of the leading roles in this matter belongs to crop rotation. It allows not only to balance the cycle of substances and energy, but also to optimize the conditions for crops cultivating with modern means of agriculture intensifying, while reducing the negative impact on soil and having a positive influence on the quantity and quality of the products $[1,2,3]$.

In addition, soil cultivation, which is an important agricultural destination affecting soil, plants and the environment, plays an important role in improving soil fertility and crop yields. Under mechanical effects, changes in the agrophysical properties of the soil, as well as water-air and nutritional regimes occur. Since soil cultivation is the most energy-

\footnotetext{
*Corresponding author: noskova_evgeniya@mail.ru
} 
intensive and expensive technique in agricultural production, it should be optimal both technically and economically [7-9].

The traditional method of soil cultivation in the conditions of the Kirov region is mouldboard ploughing, which, along with advantages (ensuring loosening to the depth of the arable layer, sealing plant residues, weed seeds, pests and diseases), has negative aspects - it leads to accelerated decomposition of organic matter in the soil, the formation of a "plow sole," increased water erosion and, as a result, crop failure. Therefore, the reduction of negative effects on the soil becomes increasingly relevant $[8,9,10]$. For this purpose, various resource-saving soil processing units are used, reducing the negative impact on the soil by reducing the depth and frequency of treatment and allowing several technological operations to be carried out in one pass. Minimal soil cultivation on the basis of tools for subsoil tillage is also becoming increasingly common. Their use reduces material, labor and energy costs.

Recently, various biological preparations have been increasingly used in the production of agricultural products, the use of which can stimulate plant growth, enhance the immune abilities of plants and, as a result, increase productivity. Soil microflora during its growth and development improves the soil structure, as well as accumulates nutrients in it due to mineralization of various organic and inorganic compounds. To stimulate the activity of soil microflora, various bacterial fertilizers are widely used, which contribute to the enrichment of the rhizosphere of plants by various useful microorganisms. Applied biological preparations improve nitrogen and phosphorus nutrition of plants, suppress phytopathogens, and increase utilization rates of nutrients from fertilizers and soil, increase resistance of plants to stressful situations $[11,12]$.

Thus, on the basis of the above, the purpose of the research was to study and identify the optimal combination of methods of basic and pre-sowing soil treatment, the use of biological preparations in field crop rotation.

\section{Materials and methods}

The long-term stationary three-factor experiment was established in 2011 on the experimental field of the Federal Agricultural Research Center of the North-East (Kirov region, Russian Federation), on sod-podzolic loamy soil with the following agrochemical parameters of the arable layer: $\mathrm{pH}_{\mathrm{KCl}} 4,6$; content of mobile phosphorus $160 \mathrm{mg} / \mathrm{kg}$ of soil (according to Kirsanov), exchange potassium $175 \mathrm{mg} / \mathrm{kg}$ of soil (according to Kirsanov), humus $1.7 \%$ (according to Tyurin). Studies were carried out in a crop rotation typical of the Kirov region with a high saturation of cereal crops: winter rye after occupied fallow with a vetch-oat mixture, spring wheat, pea-oat mixture for grain-hay, spring barley, spring oats.

Factor $\mathrm{A}$ in a three-factor field experiment included 2 methods of basic soil treatment: plowing to a depth of $20-22 \mathrm{~cm}$ or surface-cut treatment with a combined unit to a depth of $14-16 \mathrm{~cm}$.

Factor B included 3 methods of pre-sowing soil treatment: cultivation to a depth of 10$12 \mathrm{~cm}$ with a KPS-4 cultivator or a KBM-4,2 cultivator with input of fertilizers and subsequent sowing with grain seeder. Another variant of factor B was the simultaneous application of fertilizers, soil treatment and sowing with a APPN-2,1 combined aggregate.

Factor $\mathrm{C}$ for the first three species in crop rotation included 3 methods of introducing biological preparations: without introducing preparations, introducing Azotovite and Phosphatovite preparations either into the soil for pre-sowing treatment, or at tillering stage of grain crops at a dose of $1 \mathrm{l} / \mathrm{ha}$. For the remaining crop rotation species, this factor also included 3 methods of introducing biological preparations: without introducing preparations and introducing a biological preparation based on the strain Strepromyces hygroscopicus A4 or a preparation Pseudobacterin-2 at a dose of $1.0 \mathrm{l} / \mathrm{ha}$ at the tillering stage of cereals. 
The absolute control is the variant with plowing of soil and pre-sowing cultivation with KPS-4 without the use of biological preparations.

Ploughing of plowland for spring cereals or occupied fallow for winter rye was carried out by a plow with pre-plows PLN-3-35 Surface-cutting treatment was carried out with a KPA-2,2 combined unit developed in the laboratory of mechanization of field husbandry of the FARC of the North-East, which simultaneously performs surface-cutting treatment with subsequent treatment of the soil by a disk section. The early-spring harrowing of a plowland was carried out in all studied variants with a hitch of BZSS-1.0 spike-tooth harrows of average weight. Application of complex fertilizers with the content of active substance N16P16K16 was carried out manually, on all plots, except for plots with a АППН-2,1 combined aggregate, at the rate of $150 \mathrm{~kg} / \mathrm{ha}$. Introduction of biological preparations was carried out by spraying of the soil or plants manually by means of the OP207 Zhuk sprayer. Harvesting of winter and spring grain crops was carried out by plots with the Sampo-500 combine, with recalculation of the obtained data by $100 \%$ purity and $14 \%$ humidity. Mowing of annual herbs for green mass and grain production was carried out in the same way by plots with recalculation of yield to dry matter, with the help of MF-73 mini-tractor.

Two species of highly productive bacteria have been found and selected in the natural environment - Azotobacter chroococum and Bacilus mucilginosus. On their basis, microbiological fertilizers were created and produced: Azotovite, which replenishes the soil with nitrogen and has protective properties against phytopathogens and pathogens of bacterial diseases; and Phosphatovite, which converts phosphorus and potassium from stationary forms to mobile (water-soluble), i.e. accessible to plants. Phosphatovite is involved in the mobilization of insoluble phosphorus compounds, thereby allowing to significantly reduce the consumption of phosphorus fertilizers, while simultaneously increasing the resistance of plants to fungal diseases [13].

Biopreparation based on local strain Streptomyces higroscopicus A4 isolated from rhizosphere of oats cv. Argamak, made in biotechnology laboratory of the FARC of the North-East, is capable of reducing morbidity and death of plants of winter rye, meadow clover and oats from root rots [14].

The preparation Pseudobacterin-2 is a biological fungicide based on rhizospheric bacteria Pseudomonas aureofaciens. Due to the ability of the strain to synthesize a number of antibiotics, Pseudobacterin-2 has its protective effect [15].

Long-term stationary experiment is established in quadruple repetition with systematic placement of variants by the method of split plots. The total number of plots is 72 (A2 * B3 $* \mathrm{C} 3 * 4)$. Based on the scheme and the method of experiment establishing, the area of the first order plot is $288 \mathrm{~m}^{2}$, the second order $-96 \mathrm{~m}^{2}$, the third $-32 \mathrm{~m}^{2}$. The counting area is proportional to the gripping width of the harvester or mower and is $17.6 \mathrm{~m}^{2}$. For sowing, cultivars of cereal and leguminous crops zoned in the Kirov region with the following sowing rates are used: $1.8 \mathrm{c} /$ ha winter rye cv. Vyatka- $2 ; 2.5 \mathrm{c} /$ ha of spring wheat cv. Svecha; $2.4 \mathrm{c} /$ ha of spring barley multi-row cv. Lel'. The sowing rate for oats cv. Selma in sole sowing was $2.4 \mathrm{c} / \mathrm{ha}$, in mixtures with legumes $-1.2 \mathrm{c} / \mathrm{ha}$ and $0.8 \mathrm{c} / \mathrm{ha}$ of spring vetch cv. Lgovskaya-28 or $1.0 \mathrm{c} /$ ha of peas cv. Luchezarny.

\section{Results and discussion}

On the scale of [16], reserves of productive moisture in the arable layer of sod-podzolic soils are estimated as "good" if they are more than $40 \mathrm{~mm}$, "satisfactory" in the range from 20 to $40 \mathrm{~mm}$, and "unsatisfactory" at values less than $20 \mathrm{~mm}$. In our studies, the differences between variants of the three-factor experiment on productive moisture reserves were not significant. At the same time, "unsatisfactory" or "good" moisture reserves was not noted at 
any years of studies; the results were in the range of 20-30 mm, which corresponds to a "satisfactory" value.

According to [16], the optimal density of the arable layer of sod-podzolic loamy soil for most agricultural crops as a whole is $1.00-1.30 \mathrm{~g} / \mathrm{cm}^{3}$. In our studies immediately after the sowing of field crops, the density of the arable layer depended on the method of basic and pre-sowing tillage; mainly regular mechanical impact led to compaction. Then, due to vegetation of plants by the second sampling period, at tillering or heading stages, soil decompression occurred to the optimal value for plant growth and development on sodpodzolic loamy soil within the range of $1.19-1.29 \mathrm{~g} / \mathrm{cm}^{3}$.

According to the scale [16], the structural state of the arable soil layer is estimated as "excellent" if it contains more than $80 \%$ of agronomical valuable aggregates with a water content of more than 70\%; "good" - $60-80 \%$ of agronomical valuable aggregates with a water content of $55-70 \%$. According to the results of our studies, due to high-quality pretreatment, all the studied variants contained more than $80 \%$ of agronomical valuable aggregates; there were no blocks and lumps. At the same time, the water stability of soil aggregates on variants with ploughing as the main soil treatment was "good," close to "excellent," in the range from 61.9 to $69.9 \%$, while in variants with surface-cut treatment it was "excellent," in the range from 70.9 to $75.4 \%$, which once again confirms its soil protection function. The higher the structural coefficient as the ratio of agronomical valuable aggregates to the sum of blocks and dust, the better the soil structure. The combination of surface cutting treatment and cultivation with a KBM-4,2 cultivator or the use of a APPN-2,1 combined aggregate in all the years of research provided the highest structural coefficient, which is primarily due to the presence of bar roller units in the design.

According to the scale [17], the degree of decomposition of linen in the soil is estimated as "strong" if 50-80\% of the fabric decomposed, "average" - 30-50\% and "weak," when 10 $30 \%$ of the fabric decomposed. The degree of decomposition of the linen as an important indicator of the biological properties of the soil in some years with an arid growing season barely exceeded $10 \%$ and ranged from 13.1 to $20.7 \%$ without significant differences in the studied variants, was assessed as "weak," which emphasizes the importance of optimal moisture availability not only for plants, but also cellulose-decomposing microorganisms. In the remaining years of research, this indicator did not have significant differences in the studied factors and did not exceed the "average" value on the D.G. Zvyagintsev scale, from 30.1 to $49.8 \%$.

The phytosanitary state of sowings, taking into account EPV, is considered "good" if the number of young weeds does not exceed $25 \mathrm{pcs} . / \mathrm{m}^{2}$, perennial $-5 \mathrm{pcs} . / \mathrm{m}^{2}$, and defeat by diseases - 10\% (according to [18]). Over the years of research, the predominant young weed plants were various species of hemp nettle (Galeopsis L.), perennial - horsetail (Eqisetum arvense L.). According to the layering criterion, weed plants belonged to the first layer, that is, they did not exceed half the height of grain crops. The number of young weeds did not depend on the studied factors and usually ranged from 20.2 to $24.5 \mathrm{pcs} . / \mathrm{m}^{2}$; the number of perennial weeds increased by a surface cutting treatment by 1.6 times compared to ploughing. It should be noted that the number of horsetail plants in all studied variants was significantly higher than EPV, which indicates an increase in the acidity of the arable layer of this area, since horsetail is an indicator of this process.

The degree of defeat of cereals with root rots was more dependent on the applied biological preparations; their introduction contributed to a reliable decrease in the number of affected plants of winter rye by $7-12 \%$, spring wheat and barley by $2-3 \%$, oats by $17 \%$ relative to variant without the use of preparations.

The yield of dry matter (d.m.) of the vetch-oat mixture was $6.89 \mathrm{t} / \mathrm{ha}$ on average on 2 repetition of study in the control (tab. 1). It was the smallest in the ploughing variant + 
KBM-4,2 cultivation + biological praparations into the soil $-6.17 \mathrm{t} / \mathrm{ha}$, which is $0.72 \mathrm{t} / \mathrm{ha}$ lower than the control.

Table 1. Efficiency of cultivation of vetch-oat mixture (average for two repetitions).

\begin{tabular}{|c|c|c|c|c|c|c|c|c|c|c|}
\hline \multirow{2}{*}{$\begin{array}{c}\text { Basic } \\
\text { treatment }\end{array}$} & $\begin{array}{c}\text { Pre-sowing } \\
\text { treatment }\end{array}$ & \multicolumn{3}{|c|}{$\mathrm{Y}^{*}, \mathrm{t} / \mathrm{ha}$} & \multicolumn{3}{c|}{$\mathrm{TP}, \%$} & \multicolumn{3}{c|}{ EEC } \\
\cline { 2 - 11 } & $\mathrm{N} / \mathrm{p}^{* *}$ & $\mathrm{As}$ & $\mathrm{Ap}$ & $\mathrm{N} / \mathrm{p}$ & $\mathrm{As}$ & $\mathrm{Ap}$ & $\mathrm{N} / \mathrm{p}$ & As & $\mathrm{Ap}$ \\
\hline Ploughing & $\mathrm{KPS}-4$ & 6.89 & 6.53 & 7.69 & 99.7 & 76.2 & 105.6 & 3.48 & 3.23 & 3.75 \\
\cline { 2 - 12 } & $\mathrm{APPN}-2,1$ & 7.19 & 7.30 & 7.80 & 104.3 & 92.6 & 105.0 & 3.82 & 3.77 & 4.01 \\
\cline { 2 - 11 } & $\mathrm{KBM}-4,2$ & 6.99 & 6.17 & 7.44 & 99.6 & 64.8 & 96.7 & 3.53 & 3.06 & 3.64 \\
\hline \multirow{3}{*}{$\begin{array}{c}\text { Surface } \\
\text { treatment }\end{array}$} & $\mathrm{KPS}-4$ & 6.63 & 7.90 & 8.21 & 96.0 & 114.3 & 122.2 & 3.40 & 3.88 & 4.02 \\
\cline { 2 - 11 } & $\mathrm{APPN}-2,1$ & 6.53 & 6.72 & 7.44 & 89.9 & 81.1 & 99.3 & 3.53 & 3.53 & 3.88 \\
\cline { 2 - 11 } & KBM-4,2 & 7.25 & 6.59 & 6.95 & 110.2 & 78.3 & 87.5 & 3.70 & 3.29 & 3.46 \\
\hline
\end{tabular}

Notes: * - Y - yield capacity, EEC - energy efficiency coefficient, TP - total profitability

$* *-\mathrm{N} / \mathrm{p}$ - no biological preparations, As - Azotovite and Phosphatovite biological preparations sprayed on soil, Ap- Azotovite and Phosphatovite preparation sprayer on plants at tillering stage

The largest yield of dry matter of the vetch-oat mixture was provided by the variant of surface-cut treatment + KPS-4 cultivation + introduction of biological preparations at the tillering stage $-8.21 \mathrm{t} / \mathrm{ha}(+1.32 \mathrm{t} / \mathrm{ha}$ to control). The energy efficiency coefficient (EEC) in this variant was 4.02 , and the total profitability of production (TP) was $122.2 \%$ at EEC = 3.48 and a profitability of $99.7 \%$ under control. The cultivation of a vetch-oat mixture in the variant ploughing $+\mathrm{KBM}-4,2$ cultivation + the introduction of biological preparations into the soil was less energy-efficient and economically profitable $(\mathrm{EEC}=3.06, \mathrm{TP}=$ $64.8 \%$ ).

The yield of winter rye in the control was $2.28 \mathrm{t} / \mathrm{ha}, \mathrm{EEC}=1.98$, the total profitability of production was $44.6 \%$ (tab. 2). The variant of surface cutting treatment + APPN-2,1 treatment + introduction of biological preparations into the soil contributed to the yield of winter rye grains at the level of $2.86 \mathrm{t} / \mathrm{ha}$, due to which the energy efficiency coefficient reached 2.43 , and the profitability level $-77.7 \%$. Similar to this variant parameters were also provided by the variant of surface-cut treatment $+\mathrm{KBM}-4,2$ cultivation + introduction of biological preparations into the soil: grain yield was $2.82 \mathrm{t} / \mathrm{ha}, \mathrm{EEC}=2.42, \mathrm{TP}=74.6 \%$.

Table 2. Efficiency of cultivation of winter rye (average for two repetitions).

\begin{tabular}{|c|c|c|c|c|c|c|c|c|c|c|}
\hline \multirow{2}{*}{$\begin{array}{c}\text { Basic } \\
\text { treatment }\end{array}$} & \multirow{2}{*}{$\begin{array}{c}\text { Pre-sowing } \\
\text { treatment }\end{array}$} & \multicolumn{3}{|c|}{$\mathrm{Y}^{*}, \mathrm{t} / \mathrm{ha}$} & \multicolumn{3}{c|}{$\mathrm{TP}, \%$} & \multicolumn{3}{c|}{ EEC } \\
\cline { 3 - 11 } & & $\mathrm{N} / \mathrm{p}^{* *}$ & $\mathrm{As}$ & $\mathrm{Ap}$ & $\mathrm{N} / \mathrm{p}$ & $\mathrm{As}$ & $\mathrm{Ap}$ & $\mathrm{N} / \mathrm{p}$ & As & $\mathrm{Ap}$ \\
\hline \multirow{3}{*}{ Ploughing } & KPS-4 & 2.28 & 2.38 & 2.51 & 44.6 & 48.2 & 56.0 & 1.98 & 2.00 & 2.10 \\
\cline { 2 - 11 } & APPN-2,1 & 2.53 & 2.67 & 2.65 & 57.0 & 62.6 & 61.4 & 2.21 & 2.27 & 2.25 \\
\cline { 2 - 11 } & KBM-4,2 & 2.59 & 2.52 & 2.67 & 61.2 & 54.3 & 63.2 & 2.23 & 2.11 & 2.23 \\
\hline \multirow{3}{*}{$\begin{array}{c}\text { Surface } \\
\text { treatment }\end{array}$} & KPS-4 & 2.47 & 2.75 & 2.71 & 59.4 & 73.7 & 71.2 & 2.17 & 2.33 & 2.30 \\
\cline { 2 - 10 } & APPN-2,1 & 2.62 & 2.86 & 2.52 & 65.6 & 77.7 & 56.7 & 2.33 & 2.43 & 2.19 \\
\cline { 2 - 10 } & KBM-4,2 & 2.55 & 2.82 & 2.70 & 61.9 & 74.6 & 68.1 & 2.24 & 2.42 & 2.29 \\
\hline
\end{tabular}

Notes: * - Y - yield capacity, EEC - energy efficiency coefficient, TP - total profitability

$* *-\mathrm{N} / \mathrm{p}$ - no biological preparations, As - Azotovite and Phosphatovite biological preparations sprayed on soil, Ap- Azotovite and Phosphatovite preparation sprayer on plants at tillering stage

Simultaneous pre-sowing treatment, application of fertilizers and sowing of spring wheat with APPN-2,1 combined aggregates after ploughing ensured production of grain yield at the level of 2.78-2.80 t/ha, regardless of application of biological applications (tab. 3 ). After surface cutting treatment, the use of this combined aggregate ensured the same yield when introducing biological preparations into the wheat at tillering stage. The lowest yield of spring wheat grain was obtained in the variant of surface-cut treatment + KBM-4,2 cultivation + introduction of biological preparations into the soil $-2.43 \mathrm{t} / \mathrm{ha}$. The yield in 
the control was $2.61 \mathrm{t} / \mathrm{ha}$ at EEC of 2.14 and a total profitability of $65.7 \%$. The most effective at cultivating spring wheat was the rejection of the use of biological preparations when combining plowing with pre-sowing treatment with APPN-2,1: energy efficiency coefficient was 2.32 at a profitability level of $73.7 \%$.

Table 3. Efficiency of cultivation of spring wheat (average for two repetitions).

\begin{tabular}{|c|c|c|c|c|c|c|c|c|c|c|}
\hline \multirow{2}{*}{$\begin{array}{c}\text { Basic } \\
\text { treatment }\end{array}$} & \multirow{2}{*}{$\begin{array}{l}\text { Pre-sowing } \\
\text { treatment }\end{array}$} & \multicolumn{3}{|c|}{$\mathrm{Y}^{*}, \mathrm{t} / \mathrm{ha}$} & \multicolumn{3}{|c|}{ TP, \% } & \multicolumn{3}{|c|}{ EEC } \\
\hline & & $\mathrm{N} / \mathrm{p}^{* *}$ & As & Ap & $\mathrm{N} / \mathrm{p}$ & As & Ap & $\mathrm{N} / \mathrm{p}$ & As & Ap \\
\hline \multirow[t]{3}{*}{ Ploughing } & KPS-4 & 2.61 & 2.72 & 2.76 & 65.7 & 69.3 & 71.0 & 2.14 & 2.17 & 2.20 \\
\hline & APPN-2,1 & 2.79 & 2.78 & 2.80 & 73.7 & 69.5 & 70.5 & 2.32 & 2.25 & 2.26 \\
\hline & KBM-4,2 & 2.71 & 2.59 & 2.74 & 69.2 & 58.7 & 67.5 & 2.22 & 2.07 & 2.18 \\
\hline \multirow{3}{*}{$\begin{array}{l}\text { Surface } \\
\text { treatment }\end{array}$} & KPS-4 & 2.67 & 2.57 & 2.65 & 72.9 & 63.3 & 67.5 & 2.23 & 2.09 & 2.15 \\
\hline & APPN-2,1 & 2.56 & 2.52 & 2.78 & 62.6 & 56.9 & 72.6 & 2.18 & 2.09 & 2.29 \\
\hline & KBM-4,2 & 2.46 & 2.43 & 2.62 & 56.9 & 52.3 & 63.2 & 2.06 & 1.98 & 2.13 \\
\hline
\end{tabular}

Notes: * - Y - yield capacity, EEC - energy efficiency coefficient, TP - total profitability

$* *-\mathrm{N} / \mathrm{p}$ - no biological preparations, As - Azotovite and Phosphatovite biological preparations sprayed on soil, Ap- Azotovite and Phosphatovite preparation sprayer on plants at tillering stage

After a three-year study of the effectiveness of the use of Azotovite and Phosphatovite biological preparations, their effectiveness was proved, so changes occurred in the scheme of three-factor experiment in factor C. Other types of biological preparations were chosen and only one method of their application was left - at the tillering stage of cereal crops.

When harvesting the pea-oat mixture for grain-hay purposes, it turned out to be the most responsive crop to the studied factors in the field experiment. Thus, even in the control, $8.10 \mathrm{t} / \mathrm{ha}$ of grain-hay was obtained in terms of dry matter (Table 4). The greatest yield of the pea oat mixture was provided by the variant of surface-cut treatment + APPN-2,1 treatment + introduction of a biologic preparation based on the strain S. hygroscopicus A4 $9.43 \mathrm{t} / \mathrm{ha}$ d.m. As a result, the energy efficiency coefficient in this variant was 4.60 , and the total profitability $-65.8 \%$ with the parameters under control 3.84 and $54.8 \%$ respectively. At the same time, the use of a biopreparation based on the strain S. hygroscopicus A4 and pre-sowing treatment with APPN-2,1, but after plowing, ensured the lowest yield $-6.81 \mathrm{t} / \mathrm{ha}$ d.m., which once again emphasizes the need for the correct combination of methods of basic, pre-sowing treatment of soil and the use of biopreparations.

Table 4. Efficiency of pea-oat mixture cultivation for grain-hay (average for two repetitions).

\begin{tabular}{|c|c|c|c|c|c|c|c|c|c|c|}
\hline \multirow{2}{*}{$\begin{array}{c}\text { Basic } \\
\text { treatment }\end{array}$} & $\begin{array}{c}\text { Pre-sowing } \\
\text { treatment }\end{array}$ & \multicolumn{3}{|c|}{$\mathrm{Y}^{*}, \mathrm{t} / \mathrm{ha}$} & \multicolumn{3}{c|}{$\mathrm{TP}, \%$} & \multicolumn{3}{c|}{ EEC } \\
\cline { 3 - 11 } & $\mathrm{N} / \mathrm{p}^{* *}$ & $\mathrm{~A} 4$ & $\mathrm{~PB}$ & $\mathrm{~N} / \mathrm{p}$ & $\mathrm{A} 4$ & $\mathrm{~PB}$ & $\mathrm{~N} / \mathrm{p}$ & $\mathrm{A} 4$ & $\mathrm{~PB}$ \\
\hline \multirow{3}{*}{ Ploughing } & $\mathrm{KPS}-4$ & 2.61 & 2.72 & 2.76 & 65.7 & 69.3 & 71.0 & 2.14 & 2.17 & 2.20 \\
\cline { 2 - 11 } & $\mathrm{APPN}-2,1$ & 2.79 & 2.78 & 2.80 & 73.7 & 69.5 & 70.5 & 2.32 & 2.25 & 2.26 \\
\cline { 2 - 11 } & $\mathrm{KBM}-4,2$ & 2.71 & 2.59 & 2.74 & 69.2 & 58.7 & 67.5 & 2.22 & 2.07 & 2.18 \\
\hline \multirow{3}{*}{$\begin{array}{c}\text { Surface } \\
\text { treatment }\end{array}$} & KPS-4 & 2.67 & 2.57 & 2.65 & 72.9 & 63.3 & 67.5 & 2.23 & 2.09 & 2.15 \\
\cline { 2 - 11 } & APPN-2,1 & 2.56 & 2.52 & 2.78 & 62.6 & 56.9 & 72.6 & 2.18 & 2.09 & 2.29 \\
\cline { 2 - 11 } & KBM-4,2 & 2.46 & 2.43 & 2.62 & 56.9 & 52.3 & 63.2 & 2.06 & 1.98 & 2.13 \\
\hline
\end{tabular}

Note: * - Y - yield capacity, EEC - energy efficiency coefficient, TP - total profitability

** - N/p - without preparations; A4 - biopreparation based on S. hygroscopicus A4 strain; PB Pseudobacterin-2 biopreparation

Spring barley was the most responsive species for classical plowing. The use of mouldboard treatment contributed to an increase in barley yields to 2.92-3.57 tons/ha. At surface cutting, it was $2.37-2.95 \mathrm{t} / \mathrm{ha}$. The greatest yield was noted in the variant combining ploughing with KPS-4 cultivation and introduction of Pseudobacterin-2. The minimum 
yield of barley grain was in the variant of surface-cut treatment with KBM-4,2 cultivation and introduction of Pseudobacterin-2 at the barley tillering stage - $2.37 \mathrm{t} / \mathrm{ha}$. In the control, the yield of barley grain was $3.40 \mathrm{t} / \mathrm{ha}$ with an energy efficiency coefficient of 2.73 and a profitability level of $114.4 \%$. Introduction of Pseudobacterin-2 biopreparation increased these parameters up to 2.78 and $118.6 \%$, respectively (tab. 5).

Table 5. Efficiency of spring barley cultivation (average for two repetitions).

\begin{tabular}{|c|c|c|c|c|c|c|c|c|c|c|}
\hline \multirow{2}{*}{$\begin{array}{c}\text { Basic } \\
\text { treatment }\end{array}$} & $\begin{array}{c}\text { Pre-sowing } \\
\text { treatment }\end{array}$ & \multicolumn{3}{|c|}{$\mathrm{Y}^{*}, \mathrm{t} / \mathrm{ha}$} & \multicolumn{3}{c|}{$\mathrm{TP}, \%$} & \multicolumn{3}{c|}{ EEC } \\
\cline { 2 - 12 } & $\mathrm{N} / \mathrm{p}^{* *}$ & $\mathrm{~A} 4$ & $\mathrm{~PB}$ & $\mathrm{~N} / \mathrm{p}$ & $\mathrm{A} 4$ & $\mathrm{~PB}$ & $\mathrm{~N} / \mathrm{p}$ & $\mathrm{A} 4$ & $\mathrm{~PB}$ \\
\hline \multirow{3}{*}{ Ploughing } & $\mathrm{KPS}-4$ & 3.40 & 3.32 & 3.57 & 114.4 & 104.9 & 118.6 & 2.73 & 2.60 & 2.78 \\
\cline { 2 - 12 } & $\mathrm{APPN}-2,1$ & 3.15 & 2.92 & 3.08 & 95.5 & 77.6 & 86.1 & 2.58 & 2.34 & 2.46 \\
\cline { 2 - 11 } & $\mathrm{KBM}-4,2$ & 3.32 & 3.15 & 3.30 & 106.4 & 91.8 & 99.7 & 2.67 & 2.48 & 2.59 \\
\hline \multirow{2}{*}{$\begin{array}{c}\text { Surface } \\
\text { treatment }\end{array}$} & $\mathrm{KPS}-4$ & 2.95 & 2.66 & 2.75 & 90.6 & 68.4 & 73.0 & 2.43 & 2.15 & 2.22 \\
\cline { 2 - 11 } & $\mathrm{APPN}-2,1$ & 2.79 & 2.79 & 2.76 & 77.1 & 73.1 & 70.4 & 2.35 & 2.28 & 2.25 \\
\cline { 2 - 11 } & KBM-4,2 & 2.84 & 2.52 & 2.37 & 80.9 & 57.4 & 47.4 & 2.35 & 2.04 & 1.93 \\
\hline
\end{tabular}

Note: $*$ - Y - yield capacity, EEC - energy efficiency coefficient, TP - total profitability

** - N/p - without preparations; A4 - biopreparation based on S. hygroscopicus A4 strain; PB Pseudobacterin-2 biopreparation

A biopreparation based on the strain S. hygroscopicus A4 was obtained from the rhizosphere of spring covered oats cv. Argamak, so in our studies its application on spring oats turned out to be especially effective; grain yield reached $3.92 \mathrm{t} / \mathrm{ha}$. It can be noted that the use of the combined sowing aggregate was effective for both plowing and surfacecutting soil treatment; the oat yield in the average on variants was 3.46 and 3.29 tons/ha, respectively (tab. 6).

Table 6. Efficiency of covered oat cultivation (average for two repetitions).

\begin{tabular}{|c|c|c|c|c|c|c|c|c|c|c|}
\hline \multirow{2}{*}{$\begin{array}{c}\text { Basic } \\
\text { treatment }\end{array}$} & \multirow{2}{*}{$\begin{array}{c}\text { Pre-sowing } \\
\text { treatment }\end{array}$} & \multicolumn{3}{|c|}{$\mathrm{Y}^{*}, \mathrm{t} / \mathrm{ha}$} & \multicolumn{3}{|c|}{ TP, \% } & \multicolumn{3}{|c|}{ EEC } \\
\hline & & $\mathrm{N} / \mathrm{p}^{* *}$ & A4 & $\mathrm{PB}$ & $\mathrm{N} / \mathrm{p}$ & A4 & PB & $\mathrm{N} / \mathrm{p}$ & A4 & PB \\
\hline \multirow[t]{3}{*}{ Ploughing } & KPS-4 & 2.91 & 3.15 & 2.98 & 84.4 & 94.7 & 83.6 & 2.34 & 2.45 & 2.33 \\
\hline & APPN-2,1 & 3.13 & 3.92 & 3.34 & 94.4 & 136.1 & 101.3 & 2.54 & 3.05 & 2.63 \\
\hline & KBM-4,2 & 2.73 & 2.98 & 2.89 & 70.7 & 81.8 & 75.5 & 2.20 & 2.33 & 2.26 \\
\hline \multirow{3}{*}{$\begin{array}{l}\text { Surface } \\
\text { treatment }\end{array}$} & KPS-4 & 3.31 & 3.31 & 3.16 & 113.0 & 108.2 & 98.0 & 2.68 & 2.61 & 2.50 \\
\hline & APPN-2,1 & 2.97 & 3.49 & 3.42 & 88.2 & 115.1 & 109.8 & 2.47 & 2.78 & 2.73 \\
\hline & KBM-4,2 & 3.02 & 3.13 & 3.07 & 92.0 & 94.2 & 89.7 & 2.46 & 2.48 & 2.43 \\
\hline
\end{tabular}

Note: * - Y - yield capacity, EEC - energy efficiency coefficient, TP - total profitability

** - N/p - without preparations; A4 - biopreparation based on S. hygroscopicus A4 strain; PB Pseudobacterin-2 biopreparation

The oat yield capacity in the control was obtained at the level of $2.91 \mathrm{t} / \mathrm{ha}$ with an energy efficiency coefficient of 2.34 and a total production profitability level of $84.4 \%$. The greatest efficiency parameters were in the ploughing variant + APPN-2,1 treatment + introduction of a biologic preparation based on the strain Streptomyces hygroscopicus A4: $\mathrm{EEC}=3.05, \mathrm{TP}=136.1 \%$.

\section{Conclusions}

In six-field crop rotation on sod-podzolic loamy soil with a medium degree of weeding without the use of herbicides, the following elements of crop cultivation technology can be recommended for production, most energetically and economically profitable: 
for a vetch-oat mixture on green food - surface-cut treatment with KPS-4 cultivation and introduction of Azotovite and Phosphatovite biological preparations at tillering stage;

for winter rye for grain - surface-cut treatment with KBM-4,2 cultivation or with presowing treatment with a combined aggregate APPN-2,1 and introduction of Azotovite and Phosphatovite biological preparations into the soil before sowing;

for spring wheat per grain - plowing and pre-sowing treatment with APPN-2,1 combined aggregate;

for pea-oat mixture for grain-hay - surface-cut treatment and pre-sowing treatment with a APPN-2,1 combined aggregate and introduction of a biologic preparation based on the Streptomyces hygroscopicus A4 strain;

for barley for grain - ploughing with KPS-4 cultivation and introduction of Pseudobacterin-2 biopreparation;

for oats per grain - ploughing and pre-sowing treatment with a APPN-2,1 combined aggregate and introduction of a biologic preparation based on the strain Streptomyces hygroscopicus $\mathrm{A} 4$.

\section{Acknowledgment}

The research was carried out under the support of the Ministry of Science and Higher Education of the Russian Federation within the state assignment of Federal Agricultural Research Center of the North-East named N.V. Rudnitsky (theme No. 0528-2019-0091)

\section{References}

1. I.N. Listopadov, Crop rotation of the southern regions, 276 (2005)

2. S.G. Bondarenko, O.F. Gorbachenko, F.I. Gorbachenko, Zonal systems of agriculture, 2, 307 (2012)

3. L.M. Kozlova, E.N. Noskova, F.A. Popov, Theoretical and applied ecology, 3, 147-153 (2020)

4. Crop rotation and reproduction of soil fertility. Results of 30 years of stationary experience, 635 (2012)

5. V.V. Rzaeva, Agriculture, 8, 25-27 (2013)

6. Y.N. Zybarev, D.S. Fomin, E3S Web of Conferences, 222 (2020)

7. G.N. Cherkasov, S.I. Kazantsev, Vladimir farmer, 3(65), 5-8 (2013)

8. V.K. Dridiger, E.A. Kashchaev and others, Agriculture, 7, 20-23 (2015)

9. I.G. Pykhtin, A.V. Gostev , L.B. Nitchenko, Agriculture, 5, 13-15 (2015)

10. Zh. Mukhamedov, V.M. Turdaliev, A.A. Kosimov, S.K. Kuchkorov, Bulletin of Science and Creativity, 3(15), 93-98 (2017)

11. A.A. Zavalin, Achievements of science and technology AIC, 8, 9-11 (2011)

12. I.G. Shirokikh, L.M. Kozlova, A.A. Shirokikh, F.A. Popov, E.V. Tovstik, Eurasian Soil Science, 7 (50), 826-831 (2017)

13. N.I. Lyubek, M.V. Sedyakov, International Scientific Agricultural Journal, 4, 18-22 (2018)

14. I.G. Shirokikh, G.A. Batalova, O.V. Ryabova, I.I. Rusakova, Grain economy of Russia, 3(27), 52-56 (2013)

15. O.P. Gorbunov, Plant protection and quarantine, 5, 35-36 (2011)

16. A.F. Safonov, M.V. Stratonovich, Workshop on Soil Farming, 208 (1990) 
17. D.G. Zvyagintsev, Methods of soil microbiology and biochemistry, 304 (1991)

18. A.F. Safonov, I.G. Platonov, Methodology for the development of adaptive landscape systems for agriculture of the Non-Black Earth Zone, 104 (2001) 